\title{
APLIKASI PERHITUNGAN PERENCANAAN RADAR DENGAN JAVA (J2ME) MENGGUNAKAN HANDPHONE
}

\author{
Eka Wahyudi ${ }^{1}$, Taufan Faozi Rachman ${ }^{2}$ \\ ${ }^{1,2}$ Program Studi Diploma III Teknik Telekomunikasi, Purwokerto \\ 1ekawahyudi@akatelsp.ac.id
}

\begin{abstract}
ABSTRAKSI
Radio Detection and Ranging (Radar) merupakan sistem pengideraan jauh dengan sensor aktif. Bagian penting radar terdiri dari transmitter (Tx) yang dihubungkan dengan antenna transmitting yang mengirimkan gelombang elektromagnetik ke target, receiver ( $\mathrm{Rx}$ ) yang dihubungkan dengan sebuah antenna receiving akan menerima gelombang hasil pantulan dari target radar. Bagian output dari terminal transmitter akan menghasilkan sebuah persamaan sinyal S(t). Antenna Tx akan mengkonversi sinyal tersebut dan mengarahkan sinyal radio menuju target. Sinyal yang menuju ke target akan menabrak target. Dengan karakteristik target radar sebagian sinyal tersebut dipantulkan kembali menuju antenna penerima radar. Persamaan sinyal hasil pantulan, $\operatorname{Sr}(\mathrm{t})$ akan diterima antenna penerima radar dan diteruskan ke bagian penerima. Bagian penerima radar selanjutnya menganalisa persamaan sinyal $\operatorname{Sr}(\mathrm{t})$ sehingga dapat menganalisa dimana keberadaan dan jarak dari target radar. Java adalah bahasa pemrograman yang dapat digunakan untuk program aplikasi perhitungan perencanann radar ini. Java memiliki sifat portable atau tidak tergantung pada platform. Dengan begitu Java dikenal dengan istilah 'write once, run everywhere', yang berarti kode program hanya ditulis sekali, namun dapat dijalankan dibawah platform manapun tanpa harus melakukan perubahan kode program. Hand phone yang memenuhi platform standar MIDP 2.0 dan CLDC 1.1 yang dapat digunakan untuk menjalankan program ini.
\end{abstract}

Kata kunci: Radar, Java, Hand phone, MIDP \& CLDC.

\section{PENDAHULUAN}

Radar adalah suatu cara untuk mendeteksi dan menentukan jarak dari objek dengan menggunakan gelombang radio, objek dari suatu Radar dikenal dengan nama target. Selama ini program simulasi mengenai link budget Radar pada umumnya hanya dapat diaplikasikan pada media computer saja. Oleh karena itu penulis mencoba untuk membuat suatu program simulasi yang dapat diaplikasikan pada handphone sebagai media alternative selain computer. Dan untuk perangkat lunak yang akan digunakan adalah menggunakan program J2ME (Java 2 Mobile Edition) atau lebih dikenal dengan nama bahasa pemrograman Java. Agar lebih mudah dalam menghitung Link Budget Radar maka dibuatlah sebuah aplikasi pada Handphone dikarenakan bentuknya yang kecil dan mudah dibawa, dengan begitu seorang pekerja lapangan dapat menggunakan aplikasi perhitungan Link Budget Radar tanpa harus membawa sebuah computer maupun mini computer.

Permasalahan yang timbul adalah bagaimana membuat aplikasi program menggunakan bahasa pemrograman Java untuk menghitung Link Budget Radar pada media Handphone. Adapun tujuan dari penyusunan jurnal/artikel ini adalah :

a) Dapat membuat suatu aplikasi perhitungan perencanaan Radar pada Handphone.

b) Mengetahui cara membuat dan menggunakan perangkat lunak berbasis bahasa pemrograman Java yang dapat mempermudah suatu perhitungan.

c) Mengenalkan bahasa pemrograman Java sebagai salah satu Tools pada media Handphone.

Adapun manfaat dari penulisan jurnal/artikel ini antara lain adalah :

a) Dapat dijadikan sebagai bahan untuk dikembangkan lagi menggunakan aplikasi bahasa pemrograman yang lain.

b) Memaksimalkan pemanfaatan teknologi yang telah ada dengan menggunakan aplikasi Java pada Handphone. 


\section{TINJAUAN PUSTAKA}

Radio Detection And Ranging atau yang dikenal dengan nama radar adalah suatu cara untuk mendeteksi dan menentukan jarak dari objek dengan menggunakan gelombang radio, objek dari suatu radar dikenal dengan nama target. ${ }^{[3]}$ Teknologi radar dipelopori oleh penemuan Maxwell pada tahun 1865 yang meneliti tentang karakteristik perambatan gelombang elektromagnetik dan selanjutnya dikembangkan oleh percobaan Hertz pada tahun $1886^{[3]}$

Bagian-bagian radar terdiri dari Transmitter (Tx) yang dihubungkan dengan antenna Transmitting yang mengirimkan gelombang elektromagnetic ke arah target. Receiver (Rx) yang dihubungkan dengan antenna Receiving yang menerima gelombang hasil pantulan dari target radar. ${ }^{[7]}$

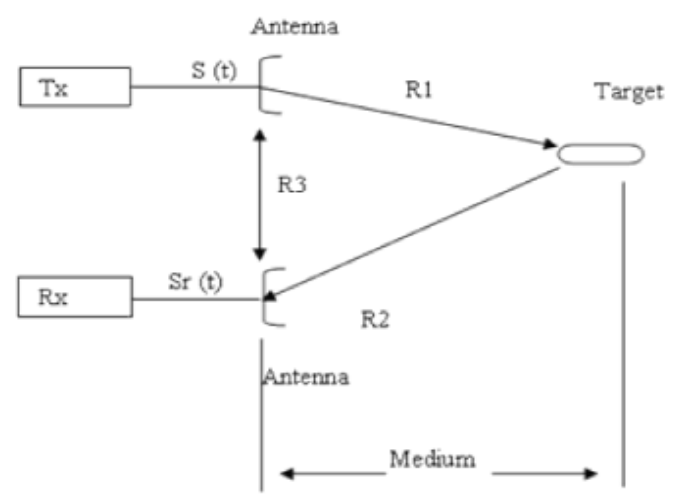

Gambar 1. Blok diagram radar Sederhana

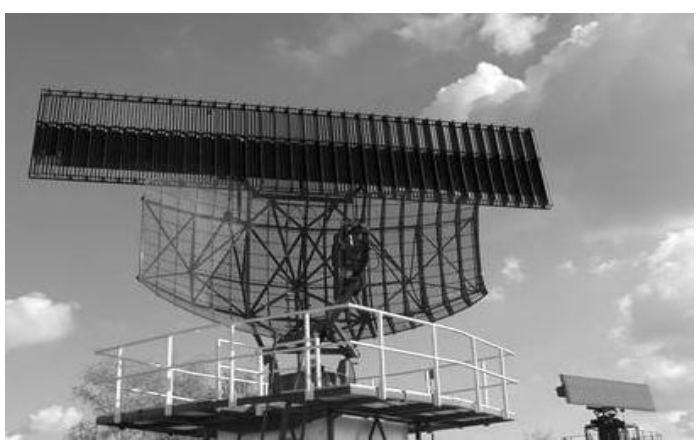

Gambar 2. Antenna radar standard

\section{Antenna Radar}

Antenna adalah suatu perangkat yang digunakan untuk mengirimkan sinyal informasi yang berasal dari pengirim dan penerima dan juga merubah sinyal informasi menjadi sebuah gelombang elektromagnetik, selain itu antenna berfungsi sebagai penguat daya sinyal informasi yang dikirimkan dan mengubah dari gelombang RF terbimbing menjadi gelombang ruang bebas. Sistem pengarahan antenna pada gelombang mikro harus bebas hambatan, karena jika sinyal informasi yang akan dikirimkan terhalang maka sinyal tersebut tidak akan dapat mencapai ke tujuan. ${ }^{[4]}$

Salah satu yang mempengaruhi sinyal suatu antenna adalah gain directivity antenna, yaitu kemampuan antenna untuk mengirimkan gelombang elektromagnetik ke tujuan. Penguatan antenna atau gain antenna ini berarti bahwa daya yang di kirimkan oleh sebuah antenna harus lebih besar dari sumber daya sinyal informasi, hal ini dikarenakan sinyal yang dikirimkan akan menempuh jarak yang jauh sehingga memerlukan daya yang cukup besar agar sinyal informasi dapat sampai ke tujuan. Penguatan antenna yang didapat tidak mencapai nilai $100 \%$, hal ini dikarenakan adanya daya yang hilang pada tepi antenna sehingga nilai yang umumnya didapatkan adalah sebesar $50 \%$ sampai dengan $70 \%$. $^{[1]}$

Besar dari sebuah gain pada antenna adalah sebagai berikut :

$$
G_{d}=\eta\left[\frac{\pi f D}{c}\right]^{2}
$$

Keterangan :

$$
\begin{aligned}
\mathrm{G}_{\mathrm{d}} & =\text { gain directivity antenna }(\mathrm{dB}) \\
\eta & =\text { effisiensi antenna }(\%) \\
\mathrm{f} & =\text { frekuensi yang digunakan }(\mathrm{GHz}) \\
\mathrm{D} & =\text { diameter antenna }(\mathrm{m}) \\
\mathrm{c} & =\text { kecepatan udara }\left(3 \times 10^{8}\right)(\mathrm{m} / \mathrm{s})
\end{aligned}
$$

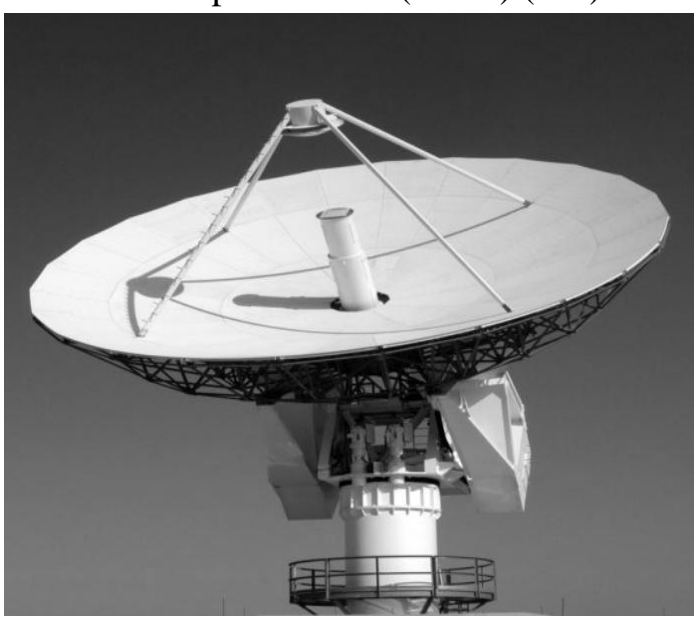

Gambar 3. Antenna 


\section{Prinsip Kerja Radar}

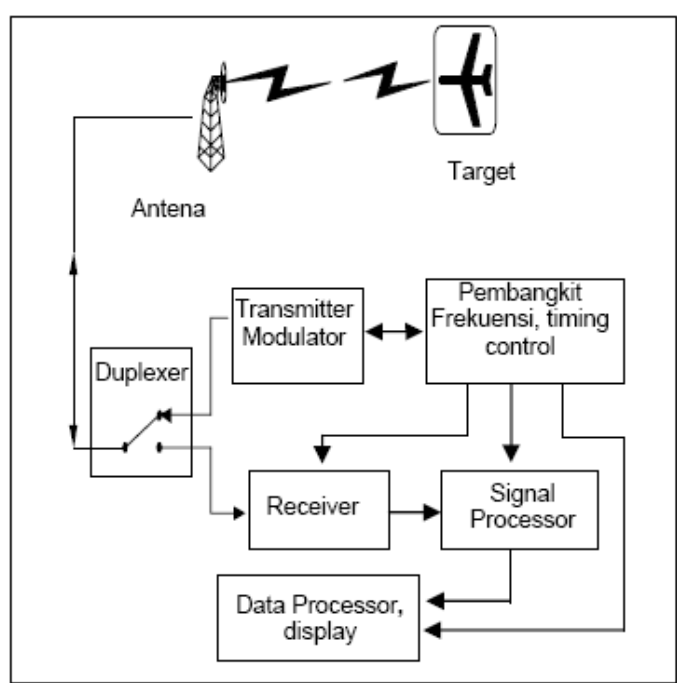

Gambar 4. Blok Diagram Prinsip Kerja Radar

Sinyal Radio yang berupa gelombang elektromagnetic dibangkitkan oleh transmitter, dan dipancarkan melalui antenna ke angkasa. Sinyal yang dipancarkan tersebut akan berpropagasi melalui atmosfer pada kecepatan dekat dengan kecepatan cahaya, yaitu memiliki medan listrik dan medan magnetik pada rasio $120 \pi(\approx 377 \Omega)$, yang merupakan impedansi atmosfer atau ruang bebas (free space). Apabila sinyal-sinyal yang dipancarkan menemukan suatu object dengan karakteristik impedansi yang berbeda dari medium tersebut, sinyal akan membentur object tersebut, dan terjadi pantulan. Sinyal pantulan tersebut diterima kembali oleh radar.

Sinyal yang diperoleh kembali oleh radar terdiri dari gema sasaran dan interferensi yang selanjutnya menuju ke processor untuk diproses. Tugas pemrosesan sinyal berupa mempertinggi gema sasaran dan menekan semua sinyal lainnya, dan mengumpulkan informasi tentang tingkah laku sasaran, termasuk posisinya, kecepatan dan karakteristiknya. ${ }^{[2]}$

Proses pengolahan sinyal memanfaatkan perbedaan antara komponen-komponen penyusun sinyal. Perbedaan tersebut dapat terjadi pada amplitudo, frekuensi dan phasa. Phasa dari gema-gema sasaran dan sinyal eferensi teratur, amplitudonya bisa teratur atau tidak. Sedangkan untuk noise amplitudo dan phasanya acak. Dan terjadi juga perubahan phasa untuk sasaran yang bergerak terhadap radar. Sedangkan untuk sasaran tetap (stasioner) phasanya konstan, sehingga sinyal-sinyal dari sasaran yang bergerak dapat dipisahkan dari sasaran stasioner. Sinyal-sinyal yang telah diproses pada prosesor sinyal selanjutnya dibandingkan dengan suatu level referensi, biasanya tegangan, disebut pendeteksian threshold. Jika komposisi sinyal yang melewati threshold adalah gema sasaran, pendeteksian terjadi. Selanjutnya akan didapatkan informasi berupa posisi, kecepatan dan karakteristik sasaran. ${ }^{[2]}$

Radar, menerima beberapa bentuk interferensi, yang menyulitkan pendeteksian dan proses pengukuran sasaran. Jika interferensi-interferensi tersebut cukup besar, dapat menutupi seluruhnya gema-gema sasaran yang diinginkan. Interferensi tersebut dapat juga menyebabkan parameter-parameter sasaran yang diukur menjadi error. Salah satu peranan pengolahan sinyal adalah untuk menekan sinyal-sinyal interferensi tersebut.

\section{Radar Basic Equation}

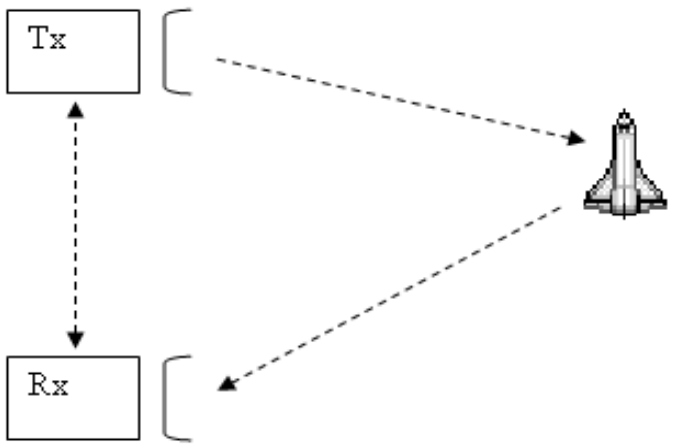

Gambar 5. Blok Diagram Radar

Blok pemancar radar memancarkan sinyal dengan daya rata-rata puncak adalah $\mathrm{P}(\mathrm{t})$, daya rata-rata ini akan menuju ke bagian antenna untuk dipancarkan. Selama perjalanan dari transmitter ke antenna Tx daya sinyal tersebut mengalami loss yang disebabkan oleh loss konektor, loss duplexer, loss isolator. Rugi-rugi sinyal selama menempuh perjalanan dari transmitter ke antenna $\mathrm{Tx}$ disebut dengan $\mathrm{L}_{\mathrm{t}}\left(\mathrm{L}_{\mathrm{t}}>1\right)$. Daya yang diterima pada bagian antenna dinotasikan sebagai $\mathrm{P}_{\mathrm{acc}}$ yang bernilai : ${ }^{[1]}$

$P_{a c c}=\frac{P_{1}}{L_{1}}$

Keterangan : 
$P_{a c c} \quad=$ daya rata-rata puncak yang diterima antenna $\mathrm{Tx}(\mathrm{W})$

$\mathrm{P}_{1} \quad=$ daya pancar sinyal radar (W)

$\mathrm{L}_{1} \quad=$ loss daya, loss yang terjadi dari transmitter menuju antenna $\mathrm{Tx}(\mathrm{dB})$

Reduksi loss juga dialami oleh bagian antenna yang diakibatkan oleh struktur antenna dan faktor panas. Loss yang terjadi pada antenna $\mathrm{Tx}$ radar dikenal dengan istilah loss radiasi $\left(\mathrm{L}_{\mathrm{rt}}\right)$. Nilai dari $\mathrm{L}_{\mathrm{n}}$ dapat didefinisikan sebagai berikut :

$$
L_{r t}=\frac{1}{\rho_{r t}} \geq 1
$$

Keterangan :

$\rho_{r t}=$ efisiensi radiasi antenna $(\%)$

$\mathrm{L}_{\mathrm{rt}}=$ loss radiasi dari transmitting antenna $(\mathrm{dB})$

Daya yang dikeluarkan oleh antenna menuju target dikenal dengan isitilah $\mathrm{P}_{\mathrm{rad}}$ di mana :

$$
P_{r a d}=\frac{P_{a c c}}{L_{r t}}=\frac{P_{t}}{L_{t} L_{r t}}
$$

Keterangan :

$\begin{array}{ll}\mathrm{P}_{\mathrm{rad}} & =\text { daya radiasi }(\mathrm{W}) \\ \mathrm{P}_{\mathrm{acc}} & =\text { daya rata-rata puncak yang }\end{array}$ diterima antenna $\mathrm{Tx}(\mathrm{W})$

$\mathrm{P}_{\mathrm{t}} \quad=$ daya pancar sinyal Radar (W)

$\mathrm{L}_{\mathrm{t}} \quad=$ loss daya, loss yang terjadi dari transmitter menuju antenna $\mathrm{Tx}(\mathrm{dB})$

$\mathrm{L}_{\mathrm{rt}}=$ loss radiasi dari transmitting antenna $(\mathrm{dB})$

Daya radiasi tersebut selama pejalanannya menuju target banyak mengalami loss yang disebut loss channel $\left(\mathrm{L}_{\mathrm{ch} 1}\right)$. Untuk menghitung daya rata-rata yang sebenarnya yang berasal dari transmisi antenna $\mathrm{Tx}$ menuju target dipengaruhi oleh semua loss tersebut adalah :

$$
{ }_{t}=\frac{\mathcal{f}_{t} G_{d t}}{4 \pi R_{1}^{2} L_{t} L_{r t} L_{c h 1}}
$$

Ketarangan :$$
\text { t \#laya pancar sinyal radar (W) }
$$$$
\mathrm{G}_{\mathrm{dt}} \quad=\text { gain directivity antenna } \mathrm{Tx}(\mathrm{dB})
$$$$
\mathrm{R}_{1}=\text { jarak antara antenna } \mathrm{Tx} \text { dengan }
$$$$
\text { target (meter) }
$$$$
\mathrm{P}_{\mathrm{t}} \quad \text { = daya rata-rata puncak }(\mathrm{W})
$$$$
\mathrm{L}_{\mathrm{t}} \quad=\text { loss daya, loss yang terjadi dari }
$$$$
\text { transmitter menuju antenna } \mathrm{Tx}
$$$$
\mathrm{L}_{\mathrm{rt}}=\text { loss radiasi dari transmitting }
$$$$
\text { antenna }(\mathrm{dB})
$$

$\mathrm{L}_{\mathrm{ch} 1}=$ loss daya yang terjadi saat proses transmitting dari antenna $\mathrm{Tx}$ ke target $(\mathrm{dB})$ Daya rata-rata yang dipantulkan oleh target menuju receiver dituliskan dibawah ini :

$$
{ }_{r t}=\frac{\mathcal{J}_{t} G_{d t} \sigma}{4 \pi R_{1}^{2} L_{t} L_{r t} L_{c h 1}}
$$

Ketarangan :

rt $\equiv$ Aaya rata-rata yang dipantulkan target (W)

$\mathrm{G}_{\mathrm{dt}} \quad=$ gain directivity antenna $\mathrm{Tx}(\mathrm{dB})$

$\mathrm{R}_{1} \quad=$ jarak antara antenna $\mathrm{Tx}$ dengan target (meter)

$\mathrm{P}_{\mathrm{t}} \quad$ = daya rata-rata puncak $(\mathrm{W})$

$\mathrm{L}_{\mathrm{t}} \quad=$ loss daya, loss yang terjadi dari transmitter menuju antenna $\mathrm{Tx}(\mathrm{dB})$

$\mathrm{L}_{\mathrm{rt}}=$ loss radiasi dari transmitting antenna $(\mathrm{dB})$

$\mathrm{L}_{\text {ch1 }}=$ loss daya yang terjadi saat proses transmitting dari antenna $\mathrm{Tx}$ ke target $(\mathrm{dB})$

$\sigma \quad=$ radar cross section $\left(\mathrm{m}^{2}\right)$

Daya rata-rata tersebut selama menempuh media transmisi dengan jarak $R_{2}$ akan terpengaruh noise, redaman yang dikenal dengan istilah $\mathrm{L}_{\mathrm{ch} 2}$ (loss yang terjadi saat proses transmisi sinyal dari target menuju antenna $\mathrm{Rx}$ ). Sehingga pada sisi antenna $\mathrm{Rx}$, daya yang diterima menjadi :

$$
{ }_{i}=\frac{\mathcal{J}_{t} G_{d t} \sigma}{(4 \pi)^{2} R_{t}^{2} L_{t} L_{r t} L_{c h 1} L_{c h 2}}
$$

Ketarangan :

i ÆAaya rata-rata pada sisi antenna penerima (W)

$\mathrm{G}_{\mathrm{dt}} \quad=$ gain directivity antenna $\mathrm{Tx}(\mathrm{dB})$

$\mathrm{R}_{1}=$ jarak antara antenna $\mathrm{Tx}$ dengan target (meter)

$\mathrm{P}_{\mathrm{t}} \quad$ = daya rata-rata puncak $(\mathrm{W})$

$\mathrm{L}_{\mathrm{t}} \quad=$ loss daya, loss yang terjadi dari transmitter menuju antenna $\mathrm{Tx}(\mathrm{dB})$

$\mathrm{L}_{\mathrm{rt}}=$ loss radiasi dari transmitting antenna $(\mathrm{dB})$

$\mathrm{L}_{\text {ch1 }}=$ loss daya yang terjadi saat proses transmitting dari antenna $\mathrm{Tx}$ ke target $(\mathrm{dB})$

$\sigma \quad=$ radar cross section $\left(\mathrm{m}^{2}\right)$

$\mathrm{L}_{\mathrm{ch} 2}=$ loss daya yang terjadi saat transmisi sinyal dari target ke antenna $\mathrm{Rx}$ $(\mathrm{dB})$

Di sisi antenna penerima juga akan ada loss radiasi antenna penerima $\left(\mathrm{L}_{\mathrm{rr}}\right)$ yang bernilai $\left(1 / \rho_{\pi}\right) \geq 1$, sehingga daya yang dikeluarkan antenna $\mathrm{Rx}$ menuju penerima Radar menjadi :

- $\quad$ Bisatic/multistatic Radar 


$$
S_{r}=\frac{p_{t} G_{d t} G_{d r} \lambda^{2} \sigma}{(4 \pi)^{3} R_{1}^{2} R_{2}^{2} L_{t} L_{r t} L_{c h 1} L_{c h 2} L_{r r}}
$$

- $\quad$ Monostatic Radar dua antenna

$$
S_{r}=\frac{p_{t} G_{d t} G_{d r} \lambda^{2} \sigma}{(4 \pi)^{3} R^{4} L_{t} L_{r t} L_{c h}^{2} L_{r r}}
$$

- $\quad$ Monostatic Radar satu antenna

$$
S_{r}=\frac{p_{t} G_{d t} G_{d r} \lambda^{2} \sigma}{(4 \pi)^{3} R^{4} L_{t} L_{c h}^{2} L_{r}^{2}}
$$

Keterangan :

$\mathrm{S}_{\mathrm{r}} \quad$ = daya yang dikeluarkan antenna $\mathrm{Rx}$ menuju penerima radar (W)

$\mathrm{G}_{\mathrm{dt}} \quad=$ gain directivity antenna $\mathrm{Tx}(\mathrm{dB})$

$\mathrm{G}_{\mathrm{dr}} \quad=$ gain directivity antenna $\mathrm{Rx}(\mathrm{dB})$

$\mathrm{R}_{1}=$ jarak antara antenna $\mathrm{Tx}$ dengan target (meter)

$\mathrm{R}_{2} \quad=$ jarak antara antenna $\mathrm{Rx}$ dengan target (meter)

$\mathrm{P}_{\mathrm{t}} \quad$ = daya rata-rata puncak $(\mathrm{W})$

$\mathrm{L}_{\mathrm{t}} \quad=$ loss daya, loss yang terjadi dari transmitter menuju antenna $\mathrm{Tx}(\mathrm{dB})$

$\mathrm{L}_{\mathrm{rt}}=$ loss radiasi dari transmitting antenna $(\mathrm{dB})$

$\mathrm{L}_{\mathrm{ch} 1}=$ loss daya yang terjadi saat proses transmitting dari antenna $\mathrm{Tx}$ ke target $(\mathrm{dB})$

$\sigma \quad=$ radar cross section $\left(\mathrm{m}^{2}\right)$

$\mathrm{L}_{\mathrm{ch} 2}=$ loss daya yang terjadi saat transmisi sinyal dari target ke receiving antenna $(\mathrm{dB})$

$\mathrm{L}_{\mathrm{rr}}=$ loss daya radiasi receiving antenna $(\mathrm{dB})$

$\lambda=$ panjang gelombang (meter)

Daya noise sistem dari antenna suatu radar memiliki persamaan sebagai berikut :

$$
\begin{aligned}
& N_{r}=k \bar{T}_{s y s} B_{N} \ldots \ldots \ldots \ldots \ldots \ldots \ldots \ldots . . . . . . . .1 \\
& \bar{T}_{s y s}=T_{a}+T_{L}\left(L_{r}-1\right)+\left(\bar{T}_{c} L_{r}\right) . .(12
\end{aligned}
$$

Keterangan :

$\mathrm{T}_{\mathrm{a}} \quad=$ antenna temperature $(\mathrm{K})$

$\bar{T}_{c} \quad=$ rata-rata efektif noise temperature

(K)

$\mathrm{L}_{\mathrm{r}} \quad=$ loss receiver $(\mathrm{dB})$

$\mathrm{T}_{\mathrm{L}} \quad=$ physical temperature $(\mathrm{K})$

$\mathrm{B}_{\mathrm{N}} \quad=$ noise bandwidth $(\mathrm{Hz})$

$\bar{T}_{\text {sys }}=$ rata-rata noise temperature sistem

(K)

$\mathrm{N}_{\mathrm{r}} \quad$ = daya noise sistem $(\mathrm{W})$

\section{Radar Cross Section}

Parameter yang sangat penting dalam perhitungan link budget dari radar. radar cross section berhubungan dengan banyaknya sinyal datang, sinyal pantul dan sinyal yang diserap oleh obyek. radar cross section juga ditentukan oleh jenis target radar yang dilihat dari sisi bentuk, volume dan sifatnya. ${ }^{[7]}$

Ketika sebuah pemancar radar memancarkan sinyalnya ke arah target, beberapa bagian dari sinyal akan memantul ke semua arah termasuk penerima dan sebagian lagi akan diserap oleh target radar. Pemantulan dan penyerapan tentunya akan menurunkan daya total pemancar radar. Jika total daya yang dipantulkan dilambangkan dengan $\sigma_{\mathrm{T}}$ dan daya yang diserap dilambangkan dengan $\sigma_{\mathrm{a}}$ maka total daya yang dikirimkan dari pemancar menjadi $\sigma_{\mathrm{c}}$ yaitu :

$\sigma_{c}=\sigma_{T}+\sigma$

Keterangan :

$\sigma_{\mathrm{T}} \quad=$ total daya dipantulkan $(\mathrm{dB})$

$\sigma_{\mathrm{a}} \quad=$ daya yang diserap $(\mathrm{dB})$

$\sigma_{\mathrm{c}} \quad=$ total daya yang dikirimkan

dari pemancar $(\mathrm{dB})$

Total cross section ditemukan dengan menjumlahkan antara bistatic dan back scattering cross section. Radar cross section dapat diartikan sebagai bagian dari Scattering / Pemantulan sinyal dari target yang berhubungan dengan sinyal polarisasi dari antenna. Radar cross section dapat dirumuskan sebagai berikut, dengan didefinisikan bahwa nilai $\sigma$ sama dengan :

$\sigma=4 \pi R^{2} \frac{P_{s}}{P_{i}}$

Keterangan :

$\sigma \quad=$ radar cross section $\left(\mathrm{m}^{2}\right)$

$\mathrm{P}_{\mathrm{s}} \quad$ = daya yang dipantulkan oleh target (W)

$\mathrm{P}_{\mathrm{i}} \quad$ = daya yang datang menju ke arah target (W)

Hubungan antara radar cross section $\sigma$ dengan polarisasi antenna adalah sebagai berikut:

$\sigma=\sigma_{s} \rho_{p o l}$

Keterangan :

$\sigma \quad=$ radar cross section $\left(\mathrm{m}^{2}\right)$

$\sigma_{\mathrm{s}} \quad=$ Scattering Cross Section

$\mathrm{P}_{\mathrm{pol}}=$ polarisasi efisiensi

Pantulan-pantulan sinyal dari clutter akan disebut sebagai Cross Section Clutter $\sigma_{\mathrm{c}}$ di mana nilainya adalah : 
$\sigma_{c}=\sigma^{o} A_{c}$

Keterangan :

$\sigma_{\mathrm{c}}=$ Cross Section Clutter $\left(\mathrm{m}^{2}\right)$

$\sigma^{\mathrm{o}}=$ Surface Backscaterring Coefisien $\left(\mathrm{m}^{2} / \mathrm{m}^{2}\right)$

$\mathrm{A}_{\mathrm{c}}=$ Efektif Clutter Scattering Area $\left(\mathrm{m}^{2}\right)$

Jika diekspresikan dalam bentuk dB maka $\sigma^{\mathrm{o}}$ akan menjadi :

$\left(\sigma^{o}\right) d B=10 \log _{10}\left(\sigma^{o}\right)$.

Besarnya daya sinyal Cross Section Clutter yang tidak diinginkan ini dapat dihitung dengan menggunakan rumus :

$S_{r c}=\frac{P_{t} G_{d}^{2} \lambda^{2} \sigma_{c}}{(4 \pi)^{3} R^{4} L}$

Keterangan:

$\mathrm{Pt}$ = daya pancar sinyal radar $(\mathrm{W})$

$\mathrm{Gd}=$ gain directivity antenna $(\mathrm{dB})$

$\lambda=$ panjang gelombang $(\mathrm{m})$

$\sigma_{\mathrm{c}} \quad=$ Cross Section scattered $\left(\mathrm{m}^{2}\right)$

$\mathrm{R}=$ jarak antara radar dengan target

yang tidak dinginkan $(\mathrm{m})$

$\mathrm{L} \quad=$ total loss $(\mathrm{dB})$

Nilai dari cross section pantulan volume target dapat dihitung dengan menggunakan rumus di bawah ini :

$\sigma_{c}=\sigma^{1} V_{c}$

Keterangan :

$\sigma_{\mathrm{c}} \quad=$ Cross Section scattered $\left(\mathrm{m}^{2}\right)$

$\sigma^{1} \quad=$ efektif scatering volume

$\mathrm{Vc}=$ Volume backscaterring koefisien $\left(\mathrm{m}^{2} / \mathrm{m}^{3}\right)$

Nilai dari $\sigma^{1}$ pada masing-masing target tersebut akan ditentukan dengan menggunakan rumus :

$\sigma_{c}=\sigma^{1} V_{c}$

$\sigma^{1}=\frac{\pi^{5}\left|K^{2}\right| a r^{b}}{\lambda^{4}}$

Keterangan:

$\mathrm{K}=$ Konstanta dielektrik dari bahan target.

$\mathrm{a}=200$

b $=1,6$

$\mathrm{r}=$ curah hujan rata-rata $(\mathrm{cm} / \mathrm{bulan})$

$\lambda \quad=$ panjang gelombang (meter)

Nilai K tersebut akan bervariasi untuk berbagai macam jenis volume target seperti hujan $(\mathrm{K} 2=0,93)$ dan untuk partikel salju $(\mathrm{K} 2=0,20)$. Sehingga nilai akhir dari daya sinyal yang dipantulkan dan bersifat clutter dari volume target akan bernilai:
$S_{r c} \frac{P_{t} G_{d}^{2} \lambda^{2} \sigma_{c}}{(4 \pi)^{3} R^{4} L}$

Keterangan:

$\mathrm{P}_{\mathrm{t}} \quad=$ daya pancar sinyal $\operatorname{radar}(\mathrm{W})$

$\mathrm{G}_{\mathrm{d}} \quad=$ gain directivity antenna $(\mathrm{W})$

$\Lambda \quad=$ panjang gelombang (meter)

$\sigma_{\mathrm{c}} \quad=$ cross section scattered $\left(\mathrm{m}^{2}\right)$

$\mathrm{R}=$ jarak antara radar dengan target yang tidak dinginkan (meter)

$\mathrm{L} \quad=$ total loss $(\mathrm{W})$

\section{Bahasa Pemrograman Java}

Java adalah bahasa pemrograman yang disusun oleh James Gosling yang dibantu oleh rekan - rekannya pada Agustus tahun 1991 di suatu perusahaan perangkat lunak yang bernama Sun Microsystem. Pada awalnya bahasa pemrograman ini diberi nama OAK, namun pada Januari tahun 1995 diganti namanya menjadi "Java" ${ }^{6]}$

Alasan utama pembentukan bahasa Java adalah untuk membuat aplikasi-aplikasi yang dapat diletakkan diberbagai macam alat elektronik, seperti microwave oven dan remote control, sehingga Java bersifat portable atau yang disebut dengan platform independent (tidak tergantung pada platform). Itulah yang menyebabkan dalam dunia pemrograman Java, dikenal adanya istilah 'write once, run everywhere', yang berarti kode program hanya ditulis sekali, namun dapat dijalankan dibawah platform manapun tanpa harus melakukan perubahan kode program $^{[6]}$

Java 2 Micro Edition (J2ME) adalah satu set spesifikasi dan teknologi yang fokus kepada perangkat konsumen. Perangkat ini memiliki jumlah memori yang terbatas, menghabiskan sedikit daya dari batere, layar yang kecil dan bandwidth jaringan yang rendah. ${ }^{[5]}$ J2ME merupakan sebuah kombinasi yang terbentuk antara sekumpulan interface Java yang sering disebut dengan Java API (Aplication Programming Interface) dengan JVM (Java Virtual Machine) yang didesain khusu untuk alat, yaitu JVM dengan ruang yang terbatas. Kombinasi tersebut kemudian digunakan untuk melakukan pembuatan aplikasi-aplikasi yang dapat berjalan di atas alat (dalam hal ini Mobile Device). Program J2ME, seperti semua program Java diterjemahkan oleh VM. Program-program tersebut dicompaile ke dalam bytecode dan 
diterjemahkan dengan JVM, hal ini berarti bahwa program-program tersebut tidak berhubungan langsung dengan perangkat. J2ME menyediakan suatu interface yang disesuaikan dengan perangkat. Aplikasiaplikasi tersebut tidak harus di compile ulang supaya mampu dijalankan pada mesin yang berbeda. Inti dari J2ME terletak pada configuration dan profile-profile. Suatu configuration menggambarkan lingkungan runtime dasar dari suatu sistem J2ME. Ia menggambarkan core library, virtual machine, vitur keamanan dan jaringan. Sebuah profile memberikan library tambahan untuk suatu kelas tertentu pada sebuah perangkat. Profile-profile menyediakan user interface (UI) API, persistence messaging library dan sebagainya. Satu set library tambahan atau package tambahan menyediakan kemampuan program tambahan. Pemasukan package ini ke dalam perangkat J2ME dapat berubah-ubah karena tergantung pada kemampuan sebuah perangkat. Sebagai contoh, beberapa perangkat MIDP tidak memiliki bluetooth build-in, sehingga bluetooth API tidak disediakan dalam perangkat ini.

\section{METODE PENELITIAN Instrument Penelitian}

Dalam pembuatan aplikasi ini peralatan yang digunakan adalah :

a) Personal Computer (PC) dengan Operating System Windows XP dengan spesifikasi Hardware Processor Pentium III ke atas, Random Access Memory (RAM) 256 ke atas sebagai media dalam menjalankan program simulasi Java yaitu JDK (Java Development Kit) versi 1.5 for Windows, Netbeans versi 5.5 for
Windows, Netbeans Mobility versi 5.5 for Windows.

b) Teknologi Telekomunikasi Handphone berbasis Java sebagai media aplikasi program. Dalam hal ini menggunakan Handphone Nokia 7210 Supernova.

\section{Variable Penelitian}

Variabel pembuatan program ini berisikan tentang parameter-parameter yang terdapat dalam perhitungan Link Budget Radar. Variabel-variabel tersebut diantaranya adalah :
a) Transmitter
a. Antenna
b. Daya rata-rata sebenarnya yang ditransmisikan antenna $\mathrm{Tx}$
c. Daya rata-rata yang dipantulkan target
b) Receiver
a. Daya rata-rata pada sisi antenna penerima
b. Daya yang dikeluarkan antenna penerima menuju receiver radar
c. Daya noise system
c) Radar Cross Section
a. Cross section clutter dari area target
b. Daya sinyal clutter dari area target
c. Cross section dari volume target
d. Daya sinyal yang dipantulkan dan bersifat clutter dari volume target

\section{Desain Penelitian}

Pada proses perancangan aplikasi ini penulis melakukan pengumpulan referensi pendukung berupa buku pustaka serta pengumpulan referensi pendukung berupa file-file melalui internet. Rancangan program perhitungan perencanaan radar ini menggunakan software Java JDK (Java Development Kit) versi 1.5 for Windows, Netbeans versi 5.5 for Windows, Netbeans Mobility versi 5.5 for Windows.

\section{HASIL DAN PEMBAHASAN Analisa Program Aplikasi}

a) Antenna
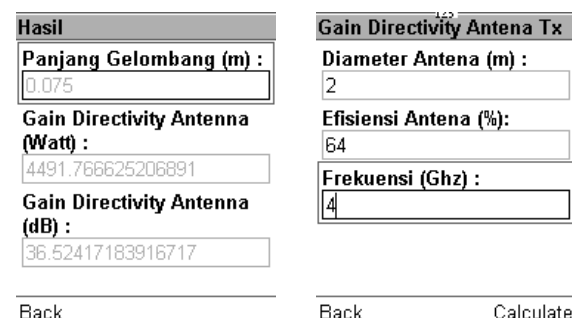

Gambar 6 Tampilan Perhitungan Gain Directivity Antenna
Dengan menggunakan program aplikasi maka didapatkan hasil penguatan antenna $T x$ : 
Dengan menggunakan program aplikasi

\begin{tabular}{ll|} 
maka & Gain Directivity Antena Rx \\
& Diameter Antena (m) : \\
\hline 5.31 \\
\\
Efisiensi Antena (\%): \\
64 \\
\hline Frekuensi (Ghz) : \\
\hline 4 \\
\hline
\end{tabular}

Back didapatkan hasil penguatan antenna $R x$

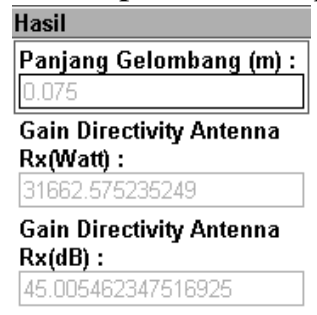

45.005462347516925

Back

Gambar 7 Tampilan Perhitungan Gain Directivity Antenna

b) Transmitter

Dengan menggunakan program aplikasi maka didapatkan hasil daya

rata-rata sebenarnya yang

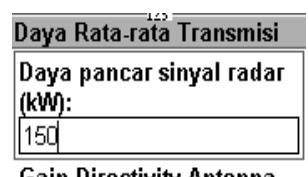

Gain Directivity Antenna

$\mathrm{Tx}(\mathrm{dB})$ :

36.52417183916717

Jarak Tx dengan target

$(\mathrm{km})$ :

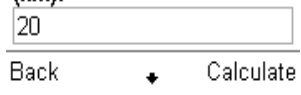

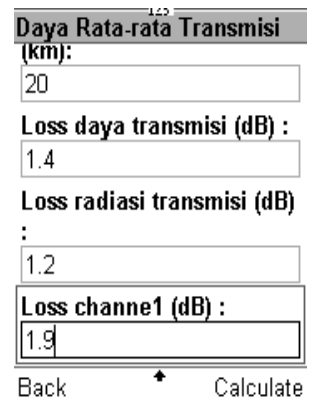

ditransmisikan antenna $T x$ menuju target :

Gambar 8 Tampilan Perhitungan Daya Rata-rata Transmisi

Dengan menggunakan program aplikasi maka didapatkan hasil daya rata-rata

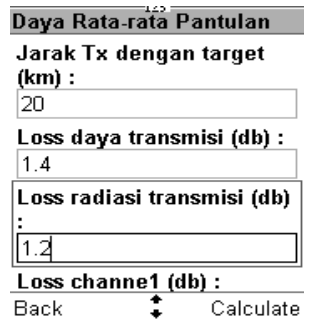

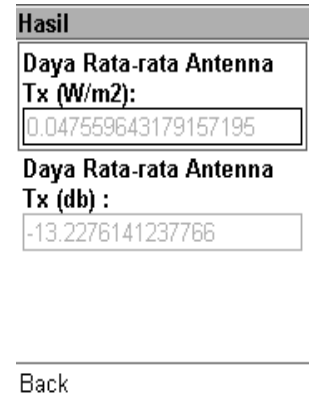


Dengan menggunakan program aplikasi maka didapatkan

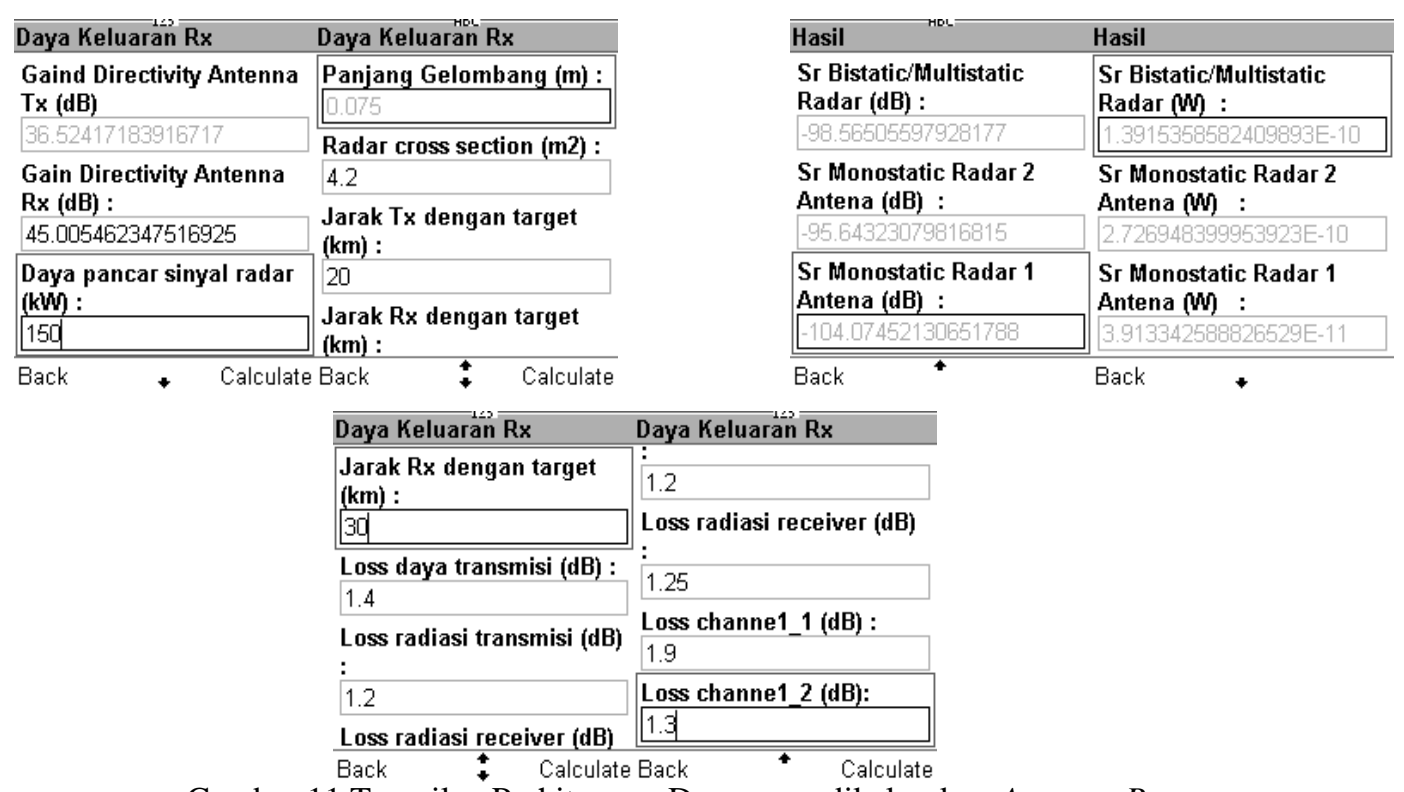

Gambar 11 Tampilan Perhitungan Daya yang dikeluarkan Antenna Rx

Dengan menggunakan

program aplikasi maka didapatkan

daya noise system :

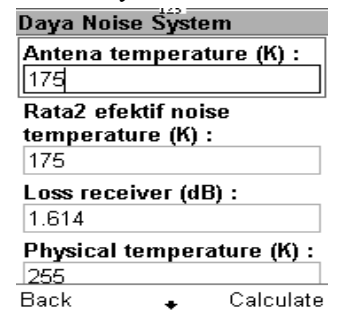

hasil daya yang dikeluarkan antenna penerima menuju receiver radar :

Gambar 12 Tampilan Perhitungan Daya Noise System

d) Cross Section

$>$ Dengan menggunakan

program aplikasi maka didapatkan
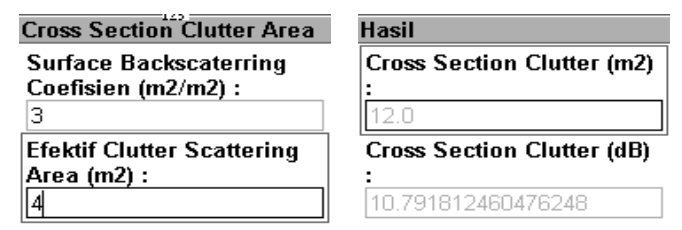

Back

Calculate Back

Gambar 13 Tampilan Perhitungan Cross Section dari Area Target

Dengan menggunakan persamaan (18) maka dapat diperoleh daya sinyal clutter dari area target sebagai berikut :

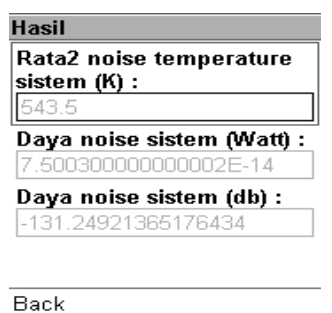

cross section clutter dari area target : 

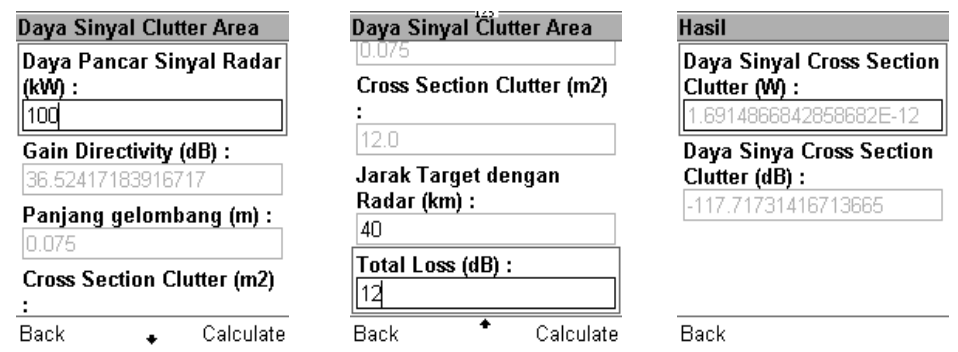

Gambar 14 Tampilan Perhitungan Daya Cross Section dari Area Target

Dengan menggunakan persamaan (20) dan (21) maka dapat diperoleh nilai dari cross section scattered dari volume target sebagai berikut :

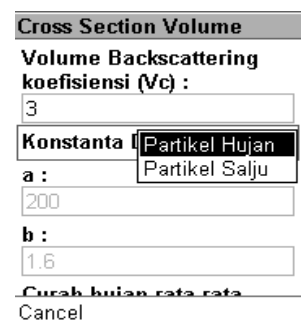

Dengan menggunakan program aplikasi maka didapatkan cross section scattered dari volume target :

Gambar 15 Tampilan Perhitungan Cross Section dari Volume Target

Dengan menggunakan persamaan (22) maka dapat diperoleh nilai dari cross section scattered dari volume target sebagai berikut :
Dengan menggunakan program aplikasi maka didapatkan daya sinyal clutter dari volume target :
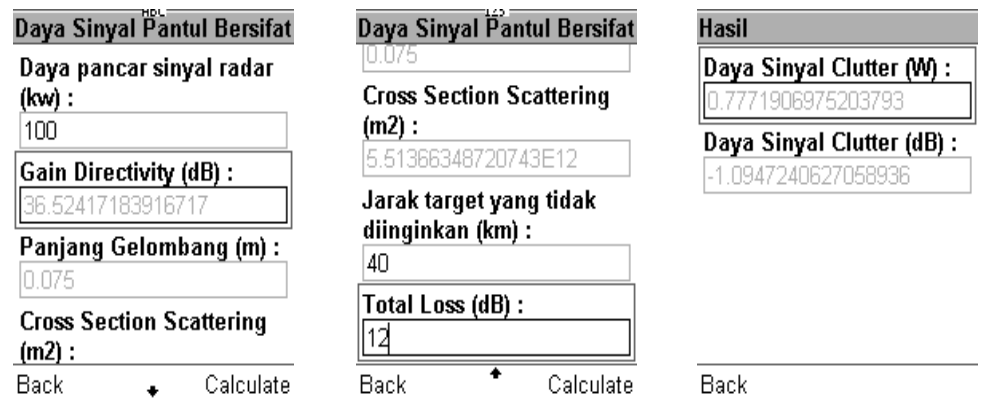

Gambar 16 Tampilan Perhitungan Daya Sinyal Clutter dari Volume Target

\section{Analisa Platform Program Aplikasi}

Program aplikasi perhitungan yang dibuat menggunakan konfigurasi Java MIDP 2.0 dan profil $C L D C$ 1.1. Konfigurasi dan profil Java tersebut dipilih karena mampu mendukung proses perhitungan yang dibutuhkan dalam program aplikasi perhitungan perencanaan radar yang telah dibuat. Pada konfigurasi inilah program aplikasi perhitungan perencanaan radar dapat bekerja.

\section{Kesimpulan dan Saran} Kesimplan

a) Semakin besar gain directivity antenna suatu radar maka akan semakin besar nilai dari daya rata-rata sebenarnya yang ditransmisikian antenna $T x$ menuju target, daya rata-rata yang dipantulkan target, daya rata-rata dari antenna $R x$, daya yang dikeluarkan antenna $R x$ meuju penerima radar.

b) Semakin besar daya sinyal pancar radar maka akan semakin besar daya yang dikeluarkan dari antenna $R x$ menuju penerima radar. 
c) Semakin besar nilai cross section suatu radar dan semakin besar nilai daya pancar sinyal radar maka akan semakin tinggi daya sinyal clutter yang terdapat pada sistem radar.

d) Hand phone yang dapat digunakan adalah hand phone yang memiliki konfigurasi MIDP 2.0 dan CLDC 1.1, hand phone yang memiliki konfigurasi di bawah standard aplikasi perhitungan perencanaan radar tidak dapat bekerja.

\section{Saran}

Sebaiknya program aplikasi perhitungan perencanaan radar ini dapat dimanfaatkan secara online. Serta dapat dikembangkan kembali melalui bahasa pemrograman lain yang hanya menghitung nilai parameterparameter untuk jenis monostatic radar, bistatic radar dan multistatic radar. Tetapi juga dapat menghitunga nilai parameterparameter dari active radar.

\section{Daftar Pustaka}

[1] Robert, G. Winch. 1993, Telecommunication Transmission System Microwave, Fiber Optic, Mobile Cellular Radio, Dataland Digital Multiplexing. Singapore.
[2] Byron Edde. 1993, Radar : Principles, Technology and Applications. Prentice-Hall, Inc.

[3] Peyton Z. Peebles, Jr. Ph. D. 1998, Radar Priciples. Canada.

[4] Freeman, Roger L. 1998, Telecommunication Transmition Handbook Fourth Edition. New York.

[5] Kadir, Abdul. 2003, Dasar Pemrograman JAVA 2. Yogyakarta, Penerbit ANDI.

[6] Haryono, A dkk. 2007, Tuntunan Pemrograman JAVA untuk Handphone. Bandung, Penerbit Informatika.

[7] Pamungkas, Wahyu. 2007, Materi Kuliah Radar. Purwokerto.

[8] http://media.diknas.go.id/media/doc ument/4743.pdf (22 Desember 2008, 19.45 wib)

[9] http://mobilezoo.biz/homepagemob ile.php?manuf $=$ nokia $\&$ handset $=6630$ (17 November 2008, 22.17 wib).

[10] http://mobilezoo.biz/homepagemob ile.php?manuf=sonyericsson\&handse $\mathrm{t}=$ K320i (17 November 2008, $22.12 \mathrm{wib})$ 